\title{
Simulation of hydrosedimentological impacts caused by climate change in the Apucaraninha River watershed, southern Brazil
}

\author{
ISABELA RAQUEL RAMOS IENSEN ${ }^{1}$, GILSON BAUER SCHULTZ ${ }^{1} \&$ \\ IRANI DOS SANTOS ${ }^{2}$ \\ 1 Universidade Federal do Paraná, Curitiba, Paraná, Brazil \\ isaiensen@gmail.com \\ 2 Departamento de Geografia da Universidade Federal do Paraná, Curitiba, Paraná, Brazil.
}

\begin{abstract}
Climate change can cause significant modifications in hydrosedimentological processes. Climate projections indicate the occurrence of extreme events, in terms of precipitation, droughts, floods and temperature. By increasing temperatures and altering precipitation regimes, climate change is expected to affect sediment dynamics. Predictions of the effects of climate change on streamflow and sediment yield vary widely, depending on the geographical location and climate scenarios used. Mathematical modelling can be used to simulate the hydrosedimentological processes in watersheds and enable the simulation of climate change effects on sediment yield. This paper aims to simulate the impacts of climate change hydrosedimentological dynamics in the Apucaraninha River watershed $\left(504 \mathrm{~km}^{2}\right)$, southern Brazil, considering the climate change scenarios A2 (pessimistic about the emissions of greenhouse gases) and B2 (optimistic about the emissions of greenhouse gases), developed by the IPCC. The Soil and Water Assessment Tool (SWAT) was used to evaluate the impacts of climate projections on the sediment yield in the Apucaraninha River watershed. The model was calibrated and validated using daily streamflow and sediment data from 1987 to 2012. The model presented satisfactory fit to the observed data allowing the reproduction of the current hydrological conditions of the watershed. Based on the satisfactory results in calibration and validation, the climate scenarios A2 and B2 were inserted to simulate streamflow and sediment conditions for the period 2071-2100. The results for both scenarios indicate that simulations of both climate scenarios resulted in changes in hydrosedimentological dynamics in the Apucaraninha River watershed, mainly in terms of decrease in average sediment yield due to the reduction in precipitation amount and increase in evapotranspiration. Our results also indicate that every $1 \%$ change in precipitation has resulted in $2.8 \%$ change in soil erosion and $1.6 \%$ change in runoff under scenario A2, and $2.3 \%$ change in erosion and $1.1 \%$ in runoff under scenarios B2, thus suggesting that climate change tends to affect sediment yield more than streamflow, although seasonally both could be impacted in similar ways.
\end{abstract}

Key words sediment; SWAT; hydrological modelling; climate change; IPCC

\section{INTRODUCTION}

Climate variability may influence hydrosedimentological processes, given that the main climate variables such as precipitation, radiation and temperature, affect streamflow and sediment dynamics. Changes in temperature could change evapotranspiration rates, affecting soil moisture and, therefore, infiltration and runoff (Pruski \& Nearing, 2002). Langbein \& Schumm (1958) reported that variations in temperature, intensity of precipitation events, number of storms and seasonal distribution of precipitation events may affect the sediment yield.

Precipitation has strong impact on soil erosion. Therefore, changes in rainfall intensity and seasonality distribution play a significant role in future erosion rates under climate change (Nearing et al., 2004; Langbein \& Schumm, 1958). Zhang \& Nearing (2005) reported that an increase in precipitation variability was often accompanied by an increase in soil loss.

According to Pruski \& Nearing (2002), the impact of climate change on precipitation patterns may be complex, differing from region to region in total precipitation, distribution through the year, and intensities. The coupled atmosphere-ocean global climate models indicate potential future changes in both the number of wet days and the percentage of precipitation coming in intense storms (McFarlane et al., 1992).

$\mathrm{Lu}$ et al. (2013) reported that quantitative assessment of the effect of climate change on sediment load is therefore of critical importance for watershed management, suggesting that the potential impacts were serious enough to warrant increased attention by conservationists on changing policies about soil and water resources.

Recognizing the importance of understanding water and sediment dynamics and elucidating the effects of climate change on the hydrosedimentological processes in watersheds, many studies 
have been conducted using hydrological modelling (Langbein \& Schumm, 1958; Pruski \& Nearing, 2002; Nearing et al., 2005; Zhang \& Nearing, 2005; Lelis et al., 2011; Lu et al., 2013). The magnitude of climate change effects on runoff and sediment yield varies, depending on the region analysed and climate scenario considered (IPCC, 2001). Due to the heterogeneity of climate conditions proposed by the scenarios, it is necessary to regionalize assessment of climate change impacts. Thus, this paper proposes to use a distributed hydrological model, the Soil and Water Assessment Tool (SWAT), to estimate potential impacts of climate change scenarios on sediment yield in the Apucaraninha River watershed located in southern Brazil.

\section{MATERIALS AND METHODS}

\subsection{Study area}

The Apucaraninha River drains an area of $504 \mathrm{~km}^{2}$ in southern Brazil $\left(50^{\circ} 56^{\prime} \mathrm{W}, 23^{\circ} 42^{\prime} \mathrm{S}\right)$ (Fig. 1). The local geomorphology consists of smooth hills, with elevation ranging from 660 to $1210 \mathrm{~m}$. Average slope of the Apucaraninha River watershed is approximately $11 \%$.

Land use in the watershed is predominantly agricultural (63\%), with soybean and wheat as major crops. The climate of the area can be classified as Humid Subtropical, characterized by high temperature and high rainfall in summer months. The average annual precipitation in the Apucaraninha River watershed is $1634 \mathrm{~mm}$.

\subsection{SWAT model application}

The SWAT model is a hydrological model developed in 1996 by the US Agricultural Research Service, Texas A\&M University and other federal agencies (Neitsch et al., 2005). It is a watershed-scale model that simulates monthly and daily streamflow, nutrient loading and sediment yield resulting from the interaction of weather, soil properties, stream channel characteristics, agricultural management and crop growth (Nearing et al. 2005). SWAT allows the simulation of



Fig. 1 Geographical location of the Apucaraninha River watershed in Southern Brazil. 
changes in land use and climate change on surface and groundwater flow, sediment yield and water quality (Srinivasan \& Arnold, 1994). SWAT estimates runoff using the Curve Number method of SCS (Soil Conservation Service) and sediment yield with the Modified Universal Soil Loss Equation (MUSLE, Williams and Berndt, 1977).

SWAT requires the input of some spatial data such as land use, soil type and a digital elevation model (DEM). Data used in this study were obtained from the climate and gauge stations located near the area studied. Rainfall and hydrosedimentological stations are shown in Fig. 1. The climate station is located $40 \mathrm{~km}$ from the Apucaraninha River watershed. The land use data were obtained by the supervised classification of digital images of LANDSAT 7 ETM +1 , bands 5, 4 and 3 (spatial resolution $30 \mathrm{~m}$ ). Definition of soil types and their physical and hydrological characteristics were obtained from EMBRAPA (1984) mapping at scale 1:600 000. The DEM has a spatial resolution of $30 \mathrm{~m}$ and used contour and point elevation data of 1:50 000 topographic maps. The watershed was partitioned into 43 sub-watersheds of equivalent size. Each subwatershed was spatially discretized in Hydrological Response Units (HRU), which are combinations of homogeneous soil types, land use, slope and management (Neitsch et al., 2005). The 43 sub-watersheds where divided into 350 HRU.

Streamflow and sediment yield from the Apucaraninha River watershed were calibrated and validated with daily measured data from 1987 to 2012. Calibration was made with observed data from 2000 to 2012 and validation with observed data from 1987 to 2000.The model was calibrated in two steps. First, a manual calibration was done to adjust the main components of water balance and sediment yield, modifying the parameters in a range usually used in the literature; then an automatic calibration was done using SWAT-CUP (Abbaspour, 2011) to achieve a good model fit.

The goodness of fit was evaluated visually as well as with the Nash-Sutcliffe coefficient efficiency (COE, Nash \& Sutcliffe, 1970), percent bias (PBIAS) and RSR (RMSE-observations standard deviation ratio). According to Moriasi et al. (2007) a satisfactory calibration consists of having a COE $>0.50$, a RSR $<0.70$, and if PBIAS $\pm 25 \%$ for streamflow and PBIAS $\pm 55 \%$ for sediment.

\subsection{Climate change scenarios}

After model calibration, data of climate scenarios A2 and B2 were used as input data in SWAT modelling. The scenarios were generated at $50-\mathrm{km}$ spatial resolution $\left(0.5^{\circ}\right.$ latitude $\times 0.5^{\circ}$ longitude $)$ and with a daily time step, using the regional climate model HadRM3P of the Hadley Centre, UK, and downscaled using the Integrated System of Regional Modelling PRECIS - PRoviding REgional Climate for Impact Studies (Marengo et al., 2009).

These climate scenarios are based on possible trends of $\mathrm{CO}_{2}$, population growth, socioeconomic development and technological changes (Marengo, 2007). The scenarios developed by IPCC compartmentalize the world in several large cells. The downscaling technique is used to regionalize data. Through downscaling, climate and weather information are regionalized in order to present detail to the particularities of each region.

The A2 scenario describes a pessimistic scenario for climate change with an increase of between $2^{\circ} \mathrm{C}$ and $5.4^{\circ} \mathrm{C}$ in temperature by 2100 (IPCC, 2001). The B2 scenario describes an optimistic scenario for climate change in which the increase in temperature varies between $1.8^{\circ} \mathrm{C}$ and $3.8^{\circ} \mathrm{C}$. The $\mathrm{A} 2$ and $\mathrm{B} 2$ emissions scenarios also indicate that global average water vapour, after evaporation and precipitation, are projected to increase, although at the regional scale both increases or decreases in precipitation are seen (IPCC, 2001).

\section{RESULTS AND DISCUSSIONS}

\subsection{Calibration and Validation}

According to the literature, some SWAT parameters were altered in order to adequately reproduce the actual hydrosedimentological conditions in Apucaraninha River watershed. Table 1 displays which parameters were modified, with a brief description of their function and the adopted value. 
Table 1 Parameters modified for simulation of runoff and sediment, their description and the adopted value.

\begin{tabular}{lll}
\hline Parameters & Description & Calibrated value \\
\hline Cn2* & SCS runoff curve number for moisture condition II & $-25 \% * * *$ \\
Alpha_bf* & Base flow Alpha factor (days) & 0.7 \\
Esco* & Soil evaporation compensation factor & 0.33 \\
Sol_awc* & Available water capacity of soil layer (mm/mm) & $50 \% * * *$ \\
Gw_delay* & Groundwaterdelay time (days) & 120 \\
Gwqmn* & Threshold water depth in shallow aquifer for flow (mm) & 400 \\
Gw_revap* & Groundwater re-evaporation coefficient & 0.15 \\
Canmx* & Maximum canopy storage (mm) & Forest $=5$ \\
& & Pasture $=2$ \\
Sol_K* & & Agriculture $=2$ \\
Revapmn* & Saturated hydraulic conductivity (mm/h) & $50 \% * * *$ \\
& Threshold depth of water in the shallow aquifer for & 200 \\
Slsubbasin* & "revap" to occur (mm) & $30 \% * * *$ \\
Lat_sed** & Average slope length (m) & 2.3 \\
Slope** & Concentration of sediment in lateral and groundwater & \\
USLE_C** & flow (mg/L) & $30 \% * * *$ \\
Ch_cov** & Average slope of subbasin (m/m) & $-50 \% * * *$ \\
\hline
\end{tabular}

*parameter used in the calibration of streamflow

** parameters used in the calibration of sediment yield

*** parameters altered based on their initial values varying percentages depending on the class, land use and soil layer referred.

Table 2 Values obtained after calibration and validation process.

\begin{tabular}{clllllll}
\hline \multirow{2}{*}{ Stage } & Time step & \multicolumn{4}{c}{ Runoff } & \multicolumn{3}{c}{ Sediment } \\
\cline { 3 - 7 } & & COE & RMR & PBIAS & COE & RMR & PBIAS \\
\hline \multirow{2}{*}{ Calibration } & Daily & 0.71 & 0.54 & 2.68 & 0.38 & 0.73 & -25.65 \\
& Monthly & 0.86 & 0.18 & 2.64 & 0.60 & 0.63 & -26.45 \\
Validation & Daily & 0.72 & 0.41 & -6.80 & 0.47 & 0.68 & -18.29 \\
& Monthly & 0.82 & 0.42 & -6.85 & 0.70 & 0.56 & -18.36 \\
\hline
\end{tabular}

Table 2 presents the values obtained in the process of calibration and validation for streamflow and sediment yield. As verified by graphs and statistical methods, the simulated runoff and sediment have a valid fit to the observed data in the calibration and validation periods.

\subsection{Climate change impacts}

The two IPCC climate change scenarios used in this study predicted that the Apucaraninha River watershed will become warmer with lower precipitation (Table 3). The main difference between the baseline and projected values was an increase of $1-2^{\circ} \mathrm{C}$ in temperature and a decrease of $366-$ $452 \mathrm{~mm}$ in precipitation.

Table 3 Comparison between values of climate variables and current values for the climate scenarios used.

\begin{tabular}{lllllll}
\hline Scenario & $\begin{array}{l}\text { TMAX } \\
\left({ }^{\circ} \mathrm{C}\right)\end{array}$ & $\begin{array}{l}\text { TMIN } \\
\left({ }^{\circ} \mathrm{C}\right)\end{array}$ & $\begin{array}{l}\text { RAD } \\
\left(\mathrm{MJ} / \mathrm{m}^{2} \text {-day }\right)\end{array}$ & $\begin{array}{l}\text { HMD } \\
(\%)\end{array}$ & $\begin{array}{l}\text { WND } \\
(\mathrm{m} / \mathrm{s})\end{array}$ & $\begin{array}{l}\text { Mean precipitation } \\
(\mathrm{mm} / \text { year })\end{array}$ \\
\hline Baseline & 27.90 & 17.30 & 14.54 & 68.90 & 2.35 & 1634.30 \\
A2 & 30.05 & 20.88 & 14.48 & 71.10 & 3.00 & 1268.40 \\
B2 & 28.79 & 19.60 & 14.56 & 72.90 & 2.62 & 1182.40 \\
\hline
\end{tabular}

TMAX: Average maximum temperature. TMIN: average minimum temperature. RAD: Average radiation. HMD: Average air relative humidity. WND: Average wind speed. 
a)

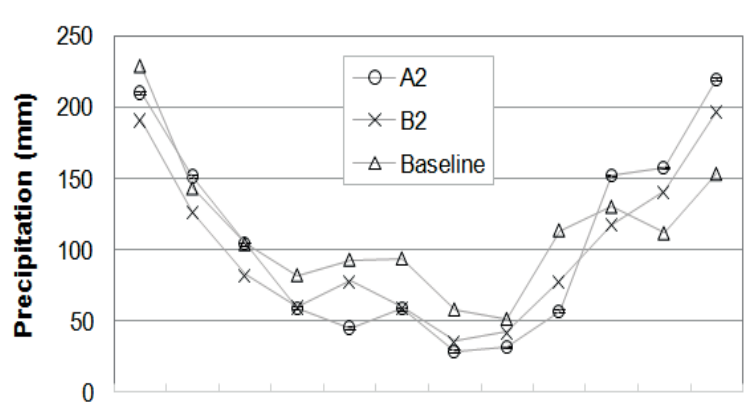

Jan Feb Mar Apr May Jun Jul Aug Sep Oct Nov Dec

c)

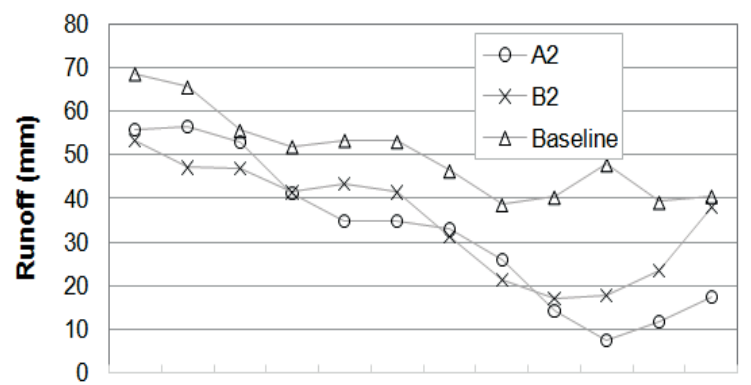

Jan Feb Mar Apr May Jun Jul Auq Sep Oct Nov Dec b)

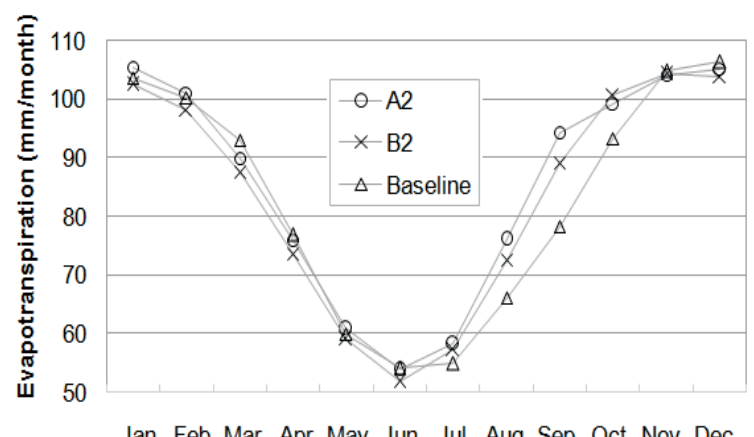

d)

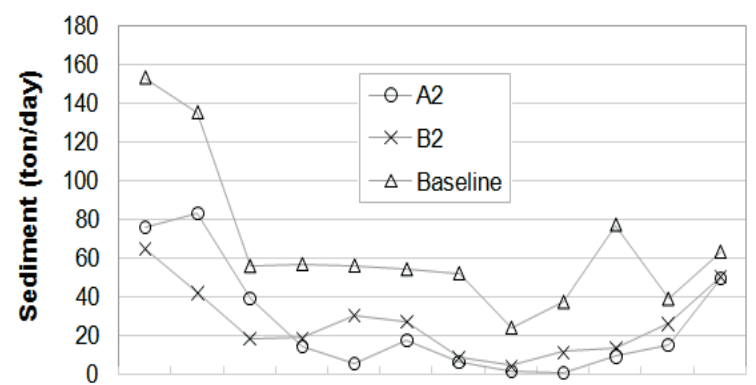

Jan Feb Mar Apr May Jun Jul Aug Sep Oct Nov Dec

Fig. 2 Simulation results for the current climate condition and for scenarios A2 and B2: (a) Mean precipitation $(\mathrm{mm})$. (b) Mean evapotranspiration $(\mathrm{mm})$. (c) Mean runoff $(\mathrm{mm})$. (d) Mean sediment yield (t/day).

In response to climate modifications, some implications are predicted in areas where climate propitiates drier conditions due to decrease in precipitation, increase in evapotranspiration rates and increase in temperatures. Figure 2 shows the seasonal change in precipitation, evapotranspiration, runoff and streamflow under the baseline and climate change conditions. Due to the reduction in annual amount of rainfall, a decrease in runoff and sediment yield was predicted. In the summer months, when temperatures are higher, evapotranspiration rates presented an upward trend coincidentally, runoff decreased significantly.

Figure 3 represents the relationship of changes in sediment and runoff with an altered change of $1 \%$ precipitation change each month. The positive relation is stronger for scenario B2 than $\mathrm{A} 2$ (Fig. 3).

a)

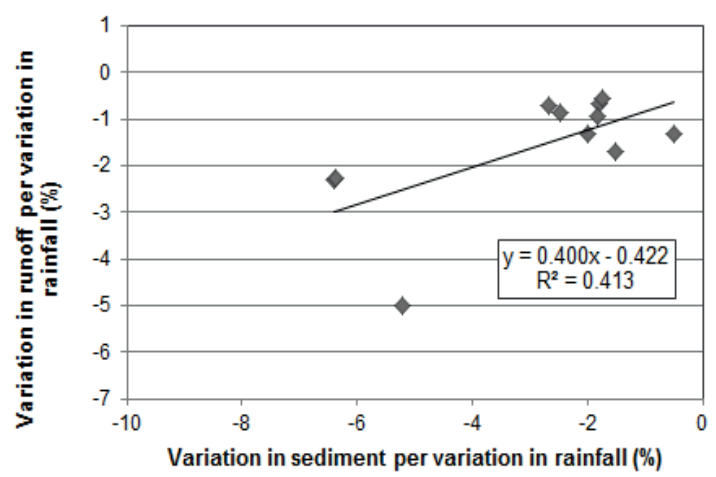

b)



Fig. 3 Monthly variation in runoff and sediment related to $1 \%$ of change in precipitation for: (a) A2 scenario, (b) B2 scenario. 
We found that $1 \%$ of change in precipitation resulted in an average $2.8 \%$ change in soil erosion and $1.6 \%$ change in runoff under scenario $\mathrm{A} 2$, and a $2.3 \%$ change in erosion and $1.1 \%$ in runoff under scenario B2. Other studies reported similar results. Pruski \& Nearing (2002) found that $1 \%$ change in precipitation could cause a $2.4 \%$ change in erosion and a $2.5 \%$ change in runoff. Lu et al. (2013) predicted a 1.3\% change in water discharge and a $2 \%$ change in sediment loads.

As reported by Nearing et al. (2005) and Lu et al. (2013), erosion is more likely to be more sensitively and more affected by climate changes (especially by precipitation changes) than runoff, though both are likely impacted in similar ways. Nearing et al. (2005) also reported that sediment yield impacts should be more severe than runoff impacts because erosion is affected by the runoff amounts as well as directly by rainfall energy and cover which protects the soil from raindrop impact and reduces rill detachment, thus the overall response to rainfall and cover changes will be greater for erosion than for runoff amounts.

a)

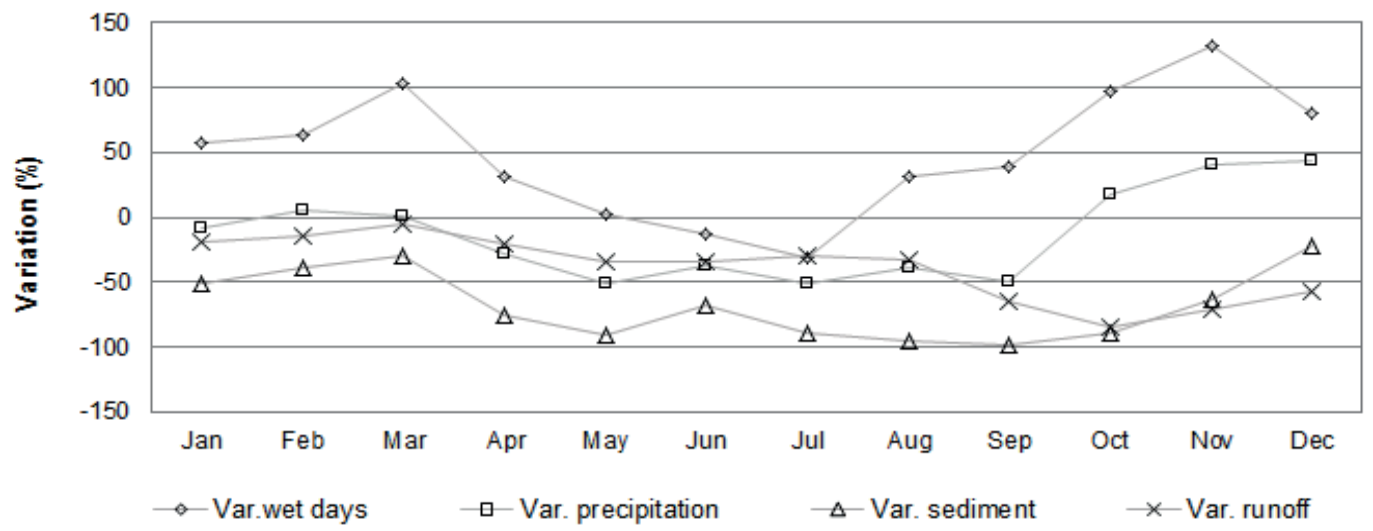

b)



Fig. 4 Var. wet days: variation of wet days (rainfall greater than $1 \mathrm{~mm}$ per day). Var. precipitation: variation of monthly precipitation. Var. Sediment: monthly variation of sediment yield. Var. Runoff: variation of runoff. (a) A2 Scenario. (b) B2 Scenario.

Figure 4 shows the variation of wet days (rainfall greater than $1 \mathrm{~mm}$ per day), precipitation, runoff and sediment yield. The occurrence of more rainfall events of low magnitude does not tend to increase the sediment yield, meaning sediment production occurs mostly in more intense precipitation events, as observed by Pruski \& Nearing (2002) who report that changes in rainfall storm intensity can be expected to have a greater impact on erosion rates than those due to changes in the number of rainy days alone

In winter months (July, August and September) the data demonstrate the lowest yields of sediment. This results from the decrease in rainfall and the upward trend in evapotranspiration. 
Winter months also showed greater difference between the amplitude of runoff and sediment. From September to December, with the increasing trend in evapotranspiration, the amplitude between values of runoff and sediment tend to equate, highlighting that the impacts on streamflow tends to be as intense as on sediments in those months.

Bogaart et al. (2003) found that sediment flux decreases during cold as well as dry events because of the decrease in erosion potential, combined with the simultaneous decrease in transport capacity. In their study, lower sediment flux was found under drier scenarios.

Similar results were reported by Lelis et al. (2011) from a simulation study on the effects of climate change on erosion processes in Minas Gerais, Brazil. They found that the reduction in precipitation caused a decrease in sediment yield and runoff. This was expected considering that a reduction in total daily precipitation and increased evapotranspiration, due to the increase in temperature. Lu et al. (2013) reported that the decrease in runoff contributed significantly to the sediment decline, ranging from $59 \%$ to $86 \%$, reducing the total runoff and, consequently, by decreasing the drag force of the particles, sediment yield.

\section{CONCLUSION}

This study shows that the SWAT model was able to reproduce the current hydrological conditions of the watershed enabling the simulation of climate scenarios to assess the impacts on the hydrological dynamics.

The results of this study showed a significant decrease in sediment yield, as well as decrease in runoff, for both scenarios $\mathrm{A} 2$ and $\mathrm{B} 2$, due to the projected decline in precipitation and the projected increase in temperature. The results indicate that each $1 \%$ of change in precipitation could result in a $2.8 \%$ change in erosion and a $1.6 \%$ change in runoff under scenario A2, and a $2.3 \%$ change in erosion and $1.1 \%$ change in runoff under scenario B2. Thus, erosion is more sensitively and more affected by climate change, especially by precipitation changes, than runoff.

In addition, the results showed the seasonality of climate data and its consequences for runoff and sediment yield in the Apucaraninha River watershed, indicating the possibility of an exacerbated decrease in precipitation amount during winter, which may reduce runoff and sediment yield.

5 Acknowledgements We thank the Conselho Nacional de Desenvolvimento Científico e Tecnológico $(\mathrm{CNPq})$ for the scholarship to the first author, the Coordenação de Aperfeiçoamento de Pessoal de Nível Superior (CAPES) for scholarship support to the second author, and also the anonymous reviewers for their insightful suggestions and comments in this paper.

\section{REFERENCES}

Abbaspour, K.C. (2011) SWAT-CUP2: SWAT Calibration and Uncertainty Programs - a user manual. Department of Systems Analysis, Integrated Assessment and Modelling (SIAM), EAWAG, Swiss Federal Institute of Aquatic Science and Technology, Duebendorf, Switzerland, 95 p.

Bogaart, P.W., et al. (2003) Process-based modelling of fluvial system response to rapid climate change. I: Model formulation and generic applications. Quaternary Science Reviews 22 (20), 2077-2095

EMBRAPA - Empresa Brasileira De Pesquisa Agropecuária (1984) Levantamento de reconhecimento dos solos do estado do Paraná. Curitiba: EMBRAPA-SNLCS/SUDESUL/IAPAR. Boletim Técnico 57. Tomos I e II.

Intergovernmental Panel on Climate Change, Working Group I (2001) Climate Change 2001: The Scientific Basis. Contribution of Working Group I to the Third Assessment Report of the IPPC. Cambridge University Press.

Langbein, W. B. \& Schumm, S. A. (1958) Yield of sediment in relation to mean annual precipitation. Am. Geophys. Union Trans 39, 1076-1084

Lelis, T.A., et al. (2011) Impactos causados pelas mudanças climáticas nos processos erosivos de uma bacia hidrográfica: Simulação de cenários. Ambi-Agua. 6(2), 282-294.

Lu, X. X.. et al. (2013). Sediment loads response to climate change: A preliminary study of eight large Chinese rivers. International Journal of Sediment Research, 28(1), 1-14.

McFarlane. N. A.. et al. (1992) The Canadian Climate Centre second-generation general circulation model and its equilibrium climate. J. Clim. 5, 1013-1044.

Marengo, J. A. (2007) Climate change and hydrological models of the wet tropics. In: M. B. Bush \& J. R. Flenley (eds), Tropical Rainforest Response to Climate Change, 237-268.

Marengo, J. A.. et al. (2009). Future change of temperature and precipitation extremes in South America as derived from the PRECIS regional climate modeling system. International Journal of Climatology, 29(15), 2241-2255. 
Moriasi, D. N., et al. (2007) Model evaluation guidelines for systematic quantification of accuracy in watershed simulations. Transactions of the ASABE 50(3),885-900.

Nash, J.E. \& Sutcliffe. J.V. (1970) River flow forecasting through conceptual models. Part I - A discussion of principles. Journal of Hydrology 10, 282-290.

Neitsch S. L., et al. (2005) Soil and water assessment tool theoretical documentation, version 2005. Grassland, soil and water research laboratory, Agricultural Research Service: Temple, Texas, USA.

Nearing, M.A., et al. (2005) Modeling response of soil erosion and runoff to changes in precipitation and cover. Catena 6, 23.

Nearing, M. A., Pruski, F. F. \& O’Neal, M. R. (2004).Expected climate change impacts on soil erosion rates: a review. Journal of Soil and Water Conservation 59(1), 43-50.

Pruski, F.F. \& Nearing, M.A. (2002). Runoff and soil-loss responses to changes in precipitation: a computer simulation study. Journal of Soil and Water Conservation 57(1), 7-16.

Srinivasan, R. \& Arnold, J.G. (1994) Integration of a basin scale water quality model with GIS. Water Resources Bull. 30(3), $453-462$.

Williams. J.R. \& Berndt. H.D. (1977). Sediment vield prediction based on watershed hydrology. Transactions of the American Society of Agricultural Engineers 20(6), 1100-1104.

Zhang. X. C. \& Nearing. M. A. (2005).Impact of climate change on soil erosion, runoff, and wheat productivity in central Oklahoma. Catena 61(2), 185-195. 